\title{
Exercises in Industrial Management
}

A Series of Case Studies 


\section{Studies in Management}

General Editor: SAMUEL EILON, D.SC. (ENG.), PH.D., D.I.C., M.I.MECH.E., M.I.PROD.E. Professor of Industrial and Management Engineering, Imperial College, London

Network ANalysis

for Planning and Scheduling

EXercises in Industrial Management

A Series of Case Studies
A. Battersby

S. Eilon, R. I. Hall, and J. R. King 


\section{Exercises in \\ Industrial Management \\ A Series of Case Studies}

Samuel Eilon, D.sC. (ENG.), PH.D.

Roger I. Hall, B.SC., A.M.I.PROD.E.

John R. King, B.SC., A.M.I.PROD.E.

Imperial College of Science and Technology, London

8

MACMILLAN

ST MARTIN'S PRESS

New York 
(C) S. EILON, R. I. HALL, J. R. KING I966

Softcover reprint of the hardcover Ist edition 1966 978-0-333-06740-6

\author{
MACMILLAN AND COMPANY LIMITED \\ Little Essex Street London $W C_{2}$ \\ also Bombay Calcutta Madras Melbourne \\ THE MACMILLAN COMPANY OF CANADA LIMITED \\ 7o Bond Street Toronto 2 \\ ST MARTIN'S PRESS INC \\ I75 Fifth Avenue New York rooro $N Y$ \\ ISBN 978-1-349-00459-I ISBN 978-1-349-00457-7 (eBook) \\ DOI $10.1007 / 978-1-349-00457-7$ \\ LIBRARY OF CONGRESS CATALOGUE CARD NO. : 66-I5056 \\ $9 \times 6$, i-viii, I-208 pages \\ 56 line illustrations
}




\section{Preface}

Case studies have become established in courses of management or business administration. Not only do they provide an excellent framework for discussion and exchange of views, particularly for students working in small groups, but they can act as a stimulant in developing the student's analytical faculties.

Much of the case material found in the literature is of a descriptive nature, and, although it serves some useful purpose, it is often inconclusive and has naturally been the subject of some criticism. We have used many case studies in our graduate courses at the Management Engineering Section at Imperial College and have developed in the course of the past few years a number which involve the use of industrial engineering and operational research techniques. Eighteen of these have been assembled in the present volume.

A selection of the material presented here could be used as a one-semester course in the American university system or as a twoterm course at British academic institutions. At Imperial College we found that these case studies can be well integrated into a 'laboratory' type course, with each case occupying the attention of a group of students for a day at the college, and many requiring additional preparation at home before the final report is submitted.

The cases in this book cover a wide range of applications, and, although many are in the field of production, there are several which involve problems in inventory control, marketing and pricing.

To avoid identifying costs, profits or prices with the currency of any one country, we adopted the term m.u. (money units) throughout this volume.

Each case study is divided into two parts: The first describes the problem which is to be analysed; the group of students should discuss this part and attempt to solve the problem before reading the second part entitled "Discussion", which provides enough material to enable the group to complete the analysis. At the end of the book there is a section which gives solutions to the cases; 
vi

some are comprehensive, others are not but are sufficiently detailed to indicate to the students whether they have tackled the case problems correctly. We hope that this 'teach yourself' feature will make this volume useful to students, teachers and practitioners alike.

December, I964.

SAMUel Eilon ROGER I. HALL JoHN R. KING 


\section{Contents}

Preface v

I Handling in a Warehouse I

2 Production Scheduling in a Biscuit Factory 6

3 Layout of a Machine Shop $\quad$ I8

4 A Feasibility Study of Tooling and Layout 35

5 Control of a Variety of Products 44

6 Production Planning in a Chemical Plant 54

7 Multi-product Batch Production 63

8 Optimal Plant Capacity 70

9 Reserve Drivers for a Bus Fleet 77

ro Machine Supervision 85

II Operator's Workload in a Chemical Plant 97

I2 Pricing Policy for Semi-perishable Goods ro6

I3 Process Planning in a Steel Plant II5

I4 Control of Manufacture of Electronic Components $\quad$ I23

I5 Deterioration of Materials in a Processing Plant $\quad \mathrm{I}_{32}$

I6 Supply Policies of a Publishing House $\mathrm{I42}^{2}$

I7 The Sportsware Dealer's Problem I5I

I8 Inspection of Incoming Goods $\quad{ }_{57}$

Solutions to Case Studies $\quad$ I67 